\title{
SOBRE O CICLO DA VIDA
}

Vinícius Bandera ${ }^{1}$

Eu já perdi o meu dia e a noite é tão breve...

A noite é uma criança!

É, mas a gente já entra nela cansado. O dia é a vida e a noite é a sobrevida e a morte. Percebe?

O que importa é a qualidade. Às vezes, a gente chega na noite com mais qualidade do que a que teve no dia.

A noite é o fim do dia. É o fim no sentido de esgotamento, de destruição, de morte. É isto: o dia é a vida e a noite é a morte.

A cada morte sucede uma vida, a cada noite sucede um novo dia.

Você está cheia de razão, mas o novo dia que surge a cada noite já não é mais o dia anterior, é outro dia. Já não é mais a mesma vida. É outra vida, a vida de outra pessoa, que é a mesma pessoa. $\mathrm{O}$ dia de cada um morre com a noite de cada um. Cada um só tem um dia e uma noite. $\mathrm{O}$ dia é para se viver e a noite é para se morrer, porque a noite é o caminho da morte. Esta é a lei da natureza, não dá para fugir dela. Você está no seu dia e eu estou na minha noite. Logo, logo, o seu dia acabará e você também entrará na sua noite.

Eu já estou chegando ao fim do meu dia!

\footnotetext{
${ }^{1}$ Pós-doutorado História Social (USP). Doutorado Sociologia (UFRJ). Mestrado Ciência Política (Unicamp). Autor dos livros Ordenação social no Brasil (Ed. UFRJ), Mulheres da vida (Multifoco), Náufragos da fé (Laço Editorial) e A genealogia em Foucault: do poder baseado na soberania ao poder panóptico (NEA Edições). Professor universitário. E-mail: viniciusbandera@gmail.com
} 
Como?

Não, você ainda tem uma boa fração do dia para aproveitar. Procure esticá-la o mais possível que puder.

Não perdendo tempo. Ocupando esse seu resto de dia pra fazer o que você mais gosta, para realizar o que for possível.

Eu tenho tanto medo da morte e você me falando essas coisas o meu medo aumentou. Acho que vou entrar em depressão.

Não, não faça isso. Não tive a intenção de fazê-la entrar em depressão. Apenas estou meditando em voz alta, como costumo fazer desde que tenho avançado em minha noite.

Eu tenho medo da noite!

Todo mundo tem. Viva, ocupe o seu dia e, mais tarde, ocupe também a sua noite, sempre que possível com as coisas e pessoas que você mais gosta. Assim você poderá conviver com a noite de uma forma menos dolorosa. Depende muito de nós, às vezes não. 